\title{
Chinaberry Aqueous Extract and Fumigant Effects on Carob Moth
}

\author{
Billal NIA*, Mohamed Kamel BEN SALAH \\ Centre for scientific and technical research on arid regions (CRSTRA), Mohamed Khider University Campus, 07000Biskra, Algeria
}

\begin{abstract}
To fight against carob moth, Ectomyelois ceratoniae (Zeller, 1879) (Lepidoptera: Pyralidae), and minimise adverse effects of conventional pesticides use, an aqueous extraction by infusion of chinaberry tree leaves, Melia azedarach (Meliaceae), was carried out. Five concentrations of chinaberry leaf aqueous extract were applied in total randomization by spraying directly on eggs, larvae and adults of carob moth under laboratory conditions. Also, the fumigant effect of chinaberry leaf powder was tested on carob moth adults. Obtained results after statistical analyses showed that eggs hatching after four days were not affected by the aqueous extract with a rate of $55 \%$ of hatching eggs in both control and treated eggs. On larvae, more than $86 \%$ of mortality at $250 \mathrm{mg} / \mathrm{ml}$ was obtained. The lethal concentrations LC $_{50}$ and LC $_{90}$ were of 121.24 and $266.74 \mathrm{mg} / \mathrm{ml}$, respectively. In the case of adults, application of aqueous extract had caused $93 \%$ of mortality at $250 \mathrm{mg} /$ $\mathrm{ml}$ after 24 hours with lethal concentrations $\mathrm{CL}_{50}$ and $\mathrm{CL}_{90}$ equal to 111.38 and $240.31 \mathrm{mg} / \mathrm{ml}$, respectively. The fumigant effect of chinaberry powdered leaves did not affect this stage. Our study showed clearly that aqueous extract of chinaberry might offer additional solution in integrated pest management strategies.
\end{abstract}

Key words: date palm, chinaberry, aqueous extract, carob moth, fumigant toxicity

\section{INTRODUCTION}

Every year carob moth still causes significant economic losses in terms of date exports by making them unmarketable. However, conventional pesticides use has diverse negative effects on environment, human health and the emergence of resistant populations of pests as well. In Integrated Pest Management programs (IPM), the development of new control methods is necessary and represents a critical segment which is emphatically preferred to persistent synthetic pesticides whose consequences on humans and biodiversity are diverse and varied in addition to the emergence of resistant populations of pests as a result of successive applications of these products to control them (Peres, 2017).

Botanicals offer a potentially safe, environmentally friendly and effective tool to suppress some threatening pests. Modern science has identified hundreds of active compounds from various parts of plants, with pesticidal, nematicidal, fungicidal, bactericidal, anti-inflammatory, antitumor, and other properties.

Melia azedarach is a botanical species in focus of global researchforitsbiologicalproperties. Thesecondarymetabolites that it contains show various biological properties, belong to different chemical groups and can be extracted from different plant parts. M. azedarach (Meliaceae) has been found to be extremely effective against insect pests (Maramoroch, 1997) and it offers many different and biologically interesting secondary metabolites. More importantly, tests showed that $M$. azedarach extract is relatively safe for different natural enemies (Arena et al., 2015).

Recently, there is a growing interest in the use of "generally recognized as safe" solvents, such as carbon dioxide, water, or ethanol (Camel, 2014). In fact, several developments have been made in recent years to minimize or completely avoid the use of solvents in the extraction step, to fulfil the requirements of green chemistry (Tobiszewski et al., 2013). 
In addition, consumption of energy has been considerably reduced. Water is a "green solvent" and can be used not only for the extraction of polar compounds but also for the extraction of slightly nonpolar compounds under the right conditions, both because of co-solubility issues and because the polarity of water decreases somewhat at high temperatures (Jones and Kinghorn, 2012).

The objective of our study is to explore the utilization of plant resource for the management of Ectomyelois ceratoniae by testing aqueous extracts of $M$. azedarach leaves on eggs, the $3^{\text {rd }}$ and $4^{\text {th }}$ instars, and adults of E. ceratoniae. We also examined the effect of leaf fumigant effect of this plant on adults of the same pest.

\section{MATERIALS AND METHODS}

\section{Biological material}

Plant material was collected from fields in Biskra in the Southeast of Algeria. It is located at $34^{\circ} 25^{\prime} 31.59^{\prime \prime} \mathrm{N}, 5^{\circ} 03^{\prime}$ 52.93" E with an elevation of 194 meters above sea level. Leaves were picked the morning and are forwarded to the laboratory. The leaves were transformed into powder using an electric mortar grinder (Retsch RM 200, Germany) and preserved in glass jars. This powder was used for testing of fumigation and for aqueous extractions by infusion for biological testing.

Individuals of $E$. ceratoniae used in this work came from a sample of infested dates given by a farmer. Next, the date moth was reared in plastic boxes on an artificial diet based on wheat bran and yeast. The rearing conditions were: $27 \pm 1$ ${ }^{\circ} \mathrm{C}$ and $35 \pm 5 \%$ relative humidity.

\section{Aqueous extract test}

We took $50 \mathrm{~g}$ from the obtained powder to extract it by infusion in $500 \mathrm{ml}$ of boiled distilled water and after 24 hours a double filtration was done by gauze. The obtained solution was evaporated in an oven at $50{ }^{\circ} \mathrm{C}$ (Memmert UN110, Germany). To assess the toxicity of the aqueous extract, thirty eggs, ten larvae, and ten adults were transferred separately to a Petri dish and sprayed with $100 \mu \mathrm{L}$ of the prepared concentrations $(50,100,150,200$, and $250 \mathrm{mg} / \mathrm{ml})$ and with water as a control with three replications. The experiment was carried out under laboratory conditions $\left(25 \pm 1{ }^{\circ} \mathrm{C}, 50\right.$ $\pm 5 \%)$. The hatched eggs were counted after 4 days, while the mortality of larvae and adults was determined after 24 hours.

\section{Fumigation test}

The powdered leaves of $M$. azedarach were put in plastic flacons (36 $\mathrm{mm}$ in diameter and $65 \mathrm{~mm}$ high). Each flacon was then placed into a plastic box (176 mm long, $124 \mathrm{~mm}$ wide and $88 \mathrm{~mm}$ deep) containing 10 non-gendered adults of E. ceratoniae. After introduction, the plastic box was immediately closed firmly so that the fumigant substances could not escape according to the protocol of Faye et al. (2014). Four doses of powdered leaves were used $(0.015,0.03$, $0.045,0.06,0.075 \mathrm{~g} / \mathrm{cm}^{3}$ ). For each dose of powdered leaves used, three repetitions were performed and a white witness without powdered leaves. The adults' mortality was evaluated after 6,12 , and 24 hours.

\section{Statistical analysis}

Mortality was compared among the treatments with the analysis of variance ANOVA and means were compared by Duncan's multiple range test at 5\% after correcting mortality following Abbott' formula (1925). Lethal concentrations $\left(\mathrm{LC}_{50}\right.$ and $\mathrm{LC}_{90}$ ) were estimated with Probit analysis using statistical program SPSS statistical software ver. 20 (IBM company, NC). Normality test with Shapiro-Wilk Test was applied for non-normal data.

\section{RESULTS}

The effectiveness of $M$. azaderach on E. ceratoniae was highlighted in this study. Two formulations (powdered leaves and leaf aqueous extract) of this plant were applied on the three development stages (eggs, larvae, and adults) of this lepidopteran.

Statistical analysis indicated that the application of leaf aqueous extract on eggs did not show ovicidal effect, whereas tests done on larvae and adults showed clearly an insecticidal effect at $5 \%$ (Table 1 ).

On larvae, aqueous extract caused more than $86 \%$ of mortality (Fig. 1). Calculated lethal concentrations $\mathrm{LC}_{50}$ and $\mathrm{LC}_{90}$ were 121.24 and $266.74 \mathrm{mg} / \mathrm{ml}$, respectively.

M. azedarach aqueous extract was also effective against adults of E. ceratoniae and caused almost 93\% of mortality (Fig. 1) with lethal concentrations $\mathrm{LC}_{50}$ and $\mathrm{LC}_{90}$ equal to 111.38 and $240.31 \mathrm{mg} / \mathrm{ml}$, respectively.

Fumigation test did not reveal negative effect on adults surviving and was proving not effective regardless of doses at $5 \%$ (Table 1 ). Indeed, the mortality rate did not exceed $0.33 \%$ (Fig. 1).

\section{DISCUSSION}

In the literature, $M$. azaderach extracts showed an insecticidal potential by using different parts of this tree (Chiffelle et al., 2011) and with different kind of organic solvents (Berlitz et al., 2012). In fact, the use of its fresh leaves in plant protection is due to their insecticidal properties.

Indeed, plant derivatives of several Meliaceae species have low ovicidal activity on different insect species (Valladares et al., 1999; Bezerra-Silva et al., 2012). Here, the studied aqueous extract showed no significant ovicidal activity with a hatching egg rate of 55\% in control and treated eggs. BezerraSilva and colleagues (2012) explained this phenomenon by the existence of egg chorion which is waterproof, so even if a Meliaceae extract reaches the eggs, it may have difficulty penetrating this barrier and causing harmful effects. 
Table 1: ANOVA and lethal concentrations of aqueous extract and fumigation tests

\begin{tabular}{|c|l|l|l|l|}
\hline & \multicolumn{1}{|c|}{$\begin{array}{c}\text { Developement } \\
\text { Stage }\end{array}$} & \multicolumn{1}{|c|}{ Signification at 5\% } & \multicolumn{1}{c|}{$\mathrm{LC}_{50}(\mathrm{mg} / \mathrm{ml})$} & \multicolumn{1}{c|}{$\mathrm{LC}_{90}(\mathrm{mg} / \mathrm{ml})$} \\
\hline \multirow{3}{*}{ Leaf aqueous extract } & Eggs & NS & $/$ & \multicolumn{1}{c|}{$/$} \\
\cline { 2 - 5 } & Larvae & $* *$ & 121.24 & 266.74 \\
\cline { 2 - 5 } & Adults & $* * *$ & 111.38 & 240.31 \\
\hline Powdered leaves & Adults & NS & $/$ & $/$ \\
\hline
\end{tabular}

LC - lethal concentration

NS: non significant

${ }^{*}$ significance at $\mathrm{P}<0.05$

${ }^{* *}$ significance at $\mathrm{P} \leq 0.01$

${ }^{* * *}$ significance at $\mathrm{P} \leq 0.001$

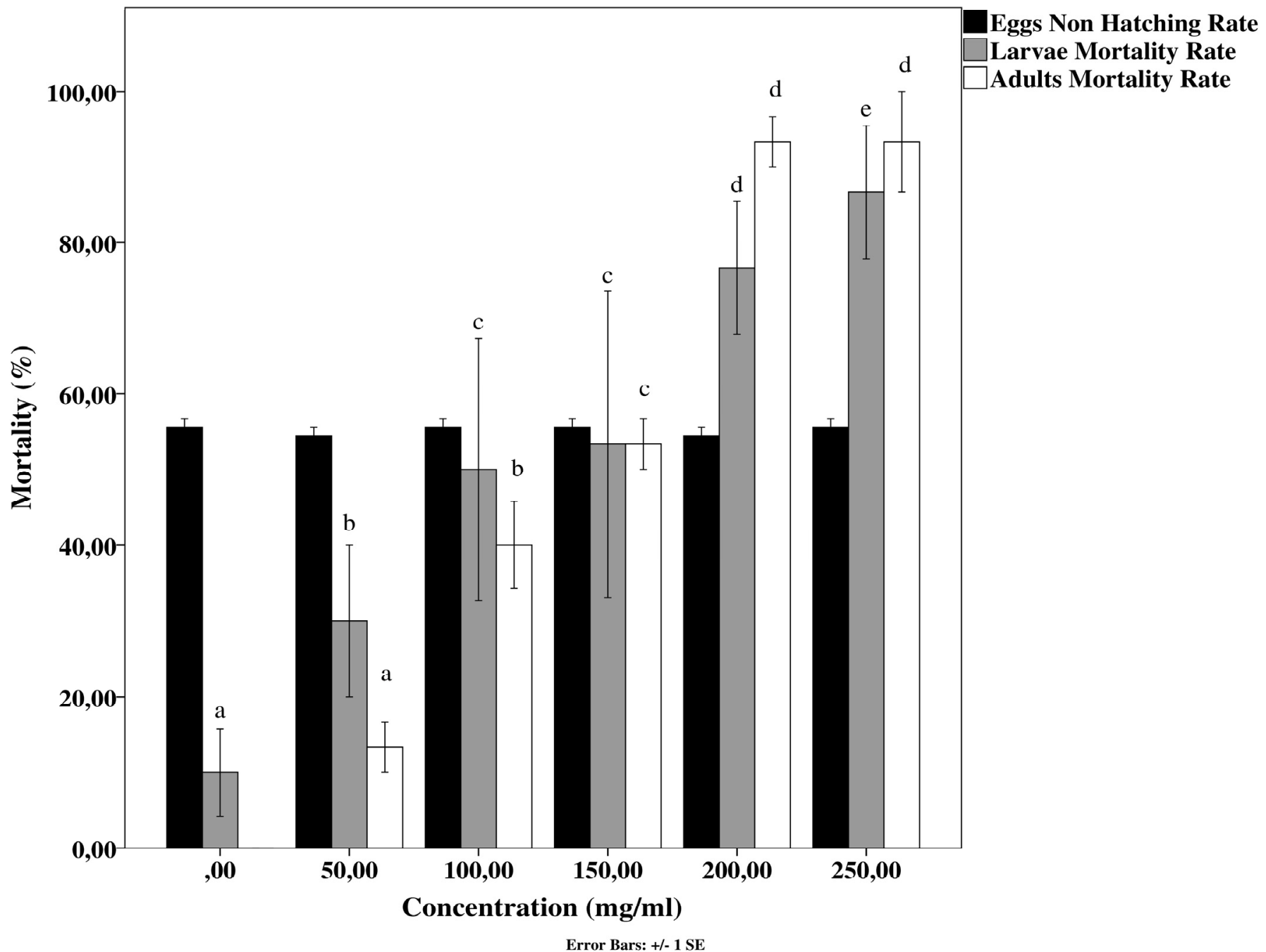

Figure 1: Mean ( \pm standard error) of unhatched eggs and mortality of Ectomyelois ceratoniae in aqueous extract test

According to Charleston (2004), the leaf aqueous extract of melia was effective in the control of larvae of Plutella xylostella (Lepidoptera: Plutelidae) causing a mortality rate which varied between $75 \%$ and $83 \%$. Berlitz and coworkers (2012) found a larvicidal effect against two insect pests Oryzophagus oryzae (Coleoptera: Curculionidae) and Spodoptera frugiperda (Lepidoptera: Noctuidae). The $\mathrm{LC}_{50}$ for O. Oryzae due to plant extract was $0.90 \mu \mathrm{g} / \mathrm{mL}$, while for $S$. frugiperda, $M$. azedarach toxins caused a $\mathrm{CL}_{50}$ of $173 \mu \mathrm{g} / \mathrm{mL}$ four days after the treatment. Also, melia leaves at $5 \%$ aqueous extract, resulted in more than $90 \%$ mortality in larvae of
Tuta absoluta (Lepidoptera: Gelechiidae) (Brunherotto and Vendramim, 2001).

Chiffelle et al. (2009) reported an insecticidal potential of the aqueous extract against adults of Drosophila melanogaster (Diptera: Drosophilidae), reaching 90\% mortality (125 000 $\mathrm{mg} \mathrm{kg}^{-1}$ ) with juvenile leaves. Other authors found positive results on adults but with fruit aqueous extract (Huerta et al., 2008).

Actually, no research work on the fumigant effect of $M$. azedarach using powdered leaves was found in the literature. However, several researchers have worked on crushed leaves 
as a fumigant of different plant species and found effectiveness against many insect species (Faye et al., 2014).

\section{CONCLUSION}

Leaf aqueous extract of $M$. azedarach was effective against larvae and adults of E. ceratoniae and this efficacy is probably due to the presence of different bioactive compound classes in leaves. Thus, the results obviously show that it will be possible to develop new ecological biopesticides. Nevertheless, further research is needed on the phytotoxicity of this extract and effect on human health.

\section{ACKNOWLEDGEMENTS}

Authors thank all date technology laboratory team for help in preparing extracts and tests.

\section{REFERENCES}

1. Abbott, W. S. (1925). A method of computing the effectiveness of an insecticide. Journal of Economic Entomology, 18, 265-267.

2. Arena, J. S., Fenoglio, M. S., Palacios, S. M., \& Defagó, M. T. (2015). Effects of Melia azedarach extract on natural enemies of aphids. Biopesticides International, 11, 1-11.

3. Berlitz, D. L., Azambuja, A. O. De, Sebben, A., Vargas, J., Oliveira, D., \& Fiuza, L. M. (2012). Mortality of Oryzophagus oryzae (Costa Lima, 1936) (Coleoptera : Curculionidae) and Spodoptera frugiperda (J E Smith, 1797) (Lepidoptera: Noctuidae) Larvae Exposed to Bacillus thuringiensis and Extracts of Melia azedarach. Brazilian Archives of Biology and Technology, 55, 725731.

4. Bezerra-Silva, G. C. D., Silva, M. A., Vendramim, J. D., \& Dias, C. T. D. S. (2012). Insecticidal and behavioral effects of secondary metabolites from meliaceae on Bemisia tabaci (Hemiptera: Aleyrodidae). Florida Entomologist, 95(3), 743-751. http://doi.org/10.1653/024.095.0325

5. Brunherotto, R., \& Vendramim, J. D. (2001). Bioatividade de Extratos Aquosos de Melia azedarach L . Sobre o Desenvolvimento de Tuta absoluta (Meyrick) (Lepidoptera : Gelechiidae) em Tomateiro. Neotropical Entomology, 30(3), 455-459.

6. Camel, V. (2014). Extraction Methodologies: General Introduction. In Encyclopedia of Analytical Chemistry (pp. 1-24). http://doi.org/10.1002/9780470027318. a9902

7. Charleston, D. S. (2004). Integrating biological control and botanical pesticides for management of Plutella Xylostella. Wageningen University, The Netherlands. Retrieved from http://library.wur.nl/WebQuery/clc/1714299

8. Chiffelle, I. G., Huerta, A. F., \& Lizana, D. R. (2009). Physical and chemical characterization of Meliaazedarach L . fruit and leaf for use as botanical insecticide. Chilean Journal of Agricultural Research, 69(1), 38-45.
9. Chiffelle, I., Huerta, A., Puga, K., \& Araya, J. E. (2011). Antifeeding and insecticide properties of aqueous and ethanolic fruit extracts from Melia azedarach L. on the elm leaf beetle Xanthogaleruca luteola Müller. Chilean Journal of Agricultural Research, 71(2), 218-225.

10. Faye, A., Thiaw, C., Sarr, M., \& Sembène, M. (2014). Effectiveness of different formulations leaves of Senna occidentalis on the external stages of Callosobruchus maculatus Fabricius main pest of cowpea (Vigna unguiculata Walp) stored. International Journal of Biosciences, 4(9), 246-253.

11. Huerta, A., Chiffelle, I., Lizana, D., \& Araya, J. E. (2008). Actividad insecticida de extractos del fruto de Melia azedarach en distintos estados de madurez sobre Drosophila melanogaster. Boletín de sanidad vegetal. Plagas, 34, 425-432.

12. Jones, W. P., \& Kinghorn, A. D. (2012). Natural Products Isolation. In S. D. Sarker \& L. Nahar (Eds.), Natural Products Isolation, Methods in Molecular Biology (Vol. 864, pp. 341-366). Springer Science+Business Media. http://doi.org/10.1007/978-1-61779-624-1

13. Maramoroch, K. (1997). Book Review: The neem tree: source of unique natural products for integrated pest management, medicine, industry and other purposes. Environmental Entomology.

14. Peres, L. L. S., Sobreiro, A. I., Couto, I. F. S., Silva, R. M., Pereira, F. F., Heredia-Vieira, S. C., ... Mussury, R. M. (2017). Chemical compounds and bioactivity of aqueous extracts of Alibertia spp. In the control of Plutella xylostella L. (Lepidoptera: Plutellidae). Insects, 8(4). http://doi.org/10.3390/insects8040125

15. Price, J. F., Schuster, D. J., \& Mcclain, P. M. (1990). Azadirachtin from neem tree (Azadirachta indica A. Juss) seeds for management of sweetpotato whitefly [Bemisia Tabaci (Gennadius)] on ornamentals. Proceedings of the Florida State Horticultural Society, 103, 186-188.

16. SPSS for Windows. (2011). Standard version (Release 20.0) SPSS Inc., Chicago, USA.

17. Tobiszewski, M., Tsakovski, S., Simeonov, V., \& Namieśnika, J. (2013). Application of multivariate statistics in assessment of green analytical chemistry parameters of analytical methodologies. Green Chemistry, 15, 1615-1623. http://doi.org/10.1039/C3GC36976E

18. Valladares, G. R., Ferreyra, D., Defago, M. T., Carpinella, M. C., \& Palacios, S. (1999). Effects of Melia azedarach on Triatoma infestans. Fitoterapia, 70(4), 421-424. http:// doi.org/10.1016/S0367-326X(99)00051-9 


\section{Vodni ekstrakt listov indijske lipovke in fumigantni učinek na rožičevo veščo}

\section{IZVLEČEK}

Z namenom boja proti rožičevi vešči Ectomyelois ceratoniae (Zeller, 1879) (Lepidoptera: Pyralidae) in za zmanjšanje škodljivih učinkov uporabe konvencionalnih pesticidov je bil izveden test učinkovitosti zatiranja $\mathrm{z}$ uporabo vodnega izvlečka listov indijske lipovke Melia azedarach (Meliaceae) ter s fumigacijo s hlapi sproščenimi iz zmletih listov. V raziskavi so v laboratorijskih pogojih preizkusili pet različnih koncentracij vodnega ekstrakta listov indijske lipovke, ki so ga popolnoma naključno razpršili neposredno na jajčeca, ličinke in odrasle osebke rožičeve vešče. Fumigantni učinek zmletih listov indijske lipovke je bil prav tako preizkušen na odraslih osebkih rožičeve vešče. Dobljeni rezultati so pokazali, da štiri dni po nanosu vodni ekstrakt nima vpliva na izleganje jajčec, saj je bila stopnja izleganja 55\% pri kontrolni in testni skupini. Pri ličinkah je bila ugotovljena preko $86 \%$ smrtnost pri koncentraciji $250 \mathrm{mg} / \mathrm{ml}$. Letalni koncentraciji LC50 in LC9o sta bili 121,24 oziroma 266,74 mg/ml. Pri odraslih osebkih je uporaba vodnega izvlečka 24 ur po nanosu povzročila $93 \%$ smrtnost pri koncentraciji $250 \mathrm{mg} / \mathrm{ml}$, pri čemer sta letalni koncentraciji CL50 in CL9o znašali 111,38 oziroma 240,31 mg/ml. Fumigantnega učinka zmletih listov indijske lipovke na odrasle vešče ni bilo. Raziskava je jasno pokazala, da ponuja vodni izvleček listov indijske lipovke dodatno rešitev v integriranih strategijah zatiranja škodljivcev.

Ključne besede: datljeva palma, indijska lipovka, vodni ekstrakt, rožičeva vešča, fumigantna toksičnost 